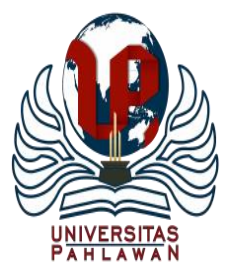

Edukatif : Jurnal Ilmu Pendidikan Volume 3 Nomor 5 Tahun 2021 Halm 2594 - 2606

EDUKATIF: JURNAL ILMU PENDIDIKAN

Research \& Learning in Education

https://edukatif.org/index.php/edukatif/index

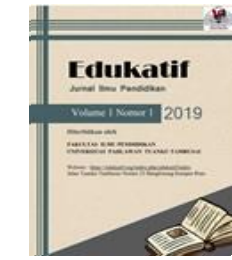

\title{
Tingkat Aktivitas Belajar Siswa pada Pembelajaran Online Pendidikan Agama Islam di Masa Pandemi Covid-19
}

\author{
Ayulia Septiani $^{1 \times}$, Muhamad Taufik Bintang Kejora ${ }^{2}$ \\ Universitas Singaperbangsa Karawang, Indonesia ${ }^{1,2}$ \\ E-mail : ayuliaseptiani11@gmail.com ${ }^{1}, \underline{\text { muhamad.taufik@ fai.unsika.ac.id }}{ }^{2}$
}

\begin{abstract}
Abstrak
Selama diintrusikan kebijakan belajar dari rumah, siswa melaksanakan pembelajaran Pendidikan Agama Islam secara online dengan memanfaatkan beragam aplikasi seperti googleclassroom, zoom, whatsapp, dan lainnya. Tujuan penelitan ini adalah untuk mengetahui tingkat aktivitas belajar siswa dan untuk mengetahui strategi pembelajaran online rumpun PAI (akidah akhlak, fiqh, sejarah kebudayaan Islam, dan Al-Qur'an Al-Hadits) di masa pandemi Covid-19 pada siswa MA Nihayatul Amal Rawamerta kabupaten Karawang. Pendekatan penelitian menggunakan pendekatan kuantitatif dengan metode survey model cross sectional. Sampel penelitian melibatkan 105 siswa dan pengumpulan data menggunakan angket berupa googleform. Analisis data menggunakan analisis deskriptif kuantitatif. Hasil penelitian menunjukkan strategi treatment atau treatment yang disiapkan oleh MA Nihayatul Amal dalam pembelajaran online adalah mengurangi durasi waktu pelajaran dan mengharuskan guru membuat resume setiap materi pembelajaran. Hasil survey menggambarkan bahwa siswa aktif dalam kehadiran di kelas online $(77,72 \%)$, mengikuti pembelajaran sampai selesai $(69,52 \%)$, mengumpulkan tugas $(91,24 \%)$, muroja'ah $(84,76 \%)$, mufrodat $(75,62 \%)$, bertanya $(64 \%)$, berdiskusi $(63,05 \%)$ dan mereview materi pembelejaran $(59,81 \%)$. Secara umum siswa MA Nihayatul Amal memiliki keaktifan belajar yang baik atau tinggi. Namun demikian aspek yang perlu ditingkatkan dan perlu mendapat perhatian serius adalah pada aspek mereview atau membaca materi pembelajaran.
\end{abstract}

Kata Kunci: Aktivitas Belajar, Pembelajaran Online, Pendidikan Agama Islam, Pandemic

\begin{abstract}
As long as the study from home policy was introduced, students carried out Islamic Religious Education learning online by utilizing various applications such as google classroom, zoom, WhatsApp, and others. The purpose of this study was to determine the level of student learning activity and to find out the online learning strategies of the PAI family (aqidah morals, fiqh, Islamic cultural history, and the Al-Qur'an Al-Hadith) during the Covid-19 pandemic in MA Nihayatul Amal Rawamerta students. Karawang district. The research approach uses a quantitative approach with a cross-sectional model survey method. The research sample involved 105 students and collected data using a questionnaire in the form of a google form. Data analysis used quantitative descriptive analysis. The results of the study show that the treatment strategy prepared by MA Nihayatul Amal in online learning is to reduce the duration of the lesson and requires the teacher to make a resume of each learning material. The survey results illustrate that students are active in online class attendance (77.72\%), following learning to completion (69.52\%), collecting assignments (91.24\%), muroja'ah (84.76\%), mufrodat ( 75.62\%), asking questions (64\%), being creative (63.05\%) and reviewing learning materials (59.81\%). In general, MA Nihayatul Amal students have a good or high learning activity. However, the aspect that needs to be improved and needs serious attention is the aspect of reviewing or reading learning materials.
\end{abstract}

Keywords: Learning Activities, Online Learning, Islamic Religious Education, Pandemic.

Copyright (c) 2021 Ayulia Septiani, Muhamad Taufik Bintang Kejora

$\triangle$ Corresponding author:

Email : ayuliaseptiani11@gmail.com

DOI : https://doi.org/10.31004/edukatif.v3i5.914

ISSN 2656-8063 (Media Cetak)

ISSN 2656-8071 (Media Online)

Edukatif : Jurnal Ilmu Pendidikan Vol 3 No 5 Tahun 2021 p-ISSN 2656-8063 e-ISSN 2656-8071 
2595 Tingkat Aktivitas Belajar Siswa Pada Pembelajaran Online Pendidikan Agama Islam di Masa Pandemi Covid-19 - Ayulia Septiani, Muhamad Taufik Bintang Kejora

DOI: https://doi.org/10.31004/edukatif.v3i5.914

\section{PENDAHULUAN}

Sejak ditetapkannya Covid-19 sebagai darurat kesehatan masyarakat (Public Health Emergency of International Concern /PHEIC) di seluruh dunia yang diumumkan oleh WHO pada pada 30 Januari 2020 (Susanna 2020), pemerintah Indonesia melalui Surat Edaran Menteri Pendidikan Kebudayaan Nomor 4 Tahun 2020 yang dikeluarkan pada 24 Maret 2020 mengumumkan penutupan sekolah selama masa pandemic (Dewi 2020). Sebagai konsekuensinya, pembelajaran tatap muka dihentikan dan proses kegiatan belajar mengajar pun hanya dimungkinkan dilaksanakan dari rumah (school from home) (Handarini 2020).

Kebijakan school from home tentunya berdampak besar pada efektivitas pembelajaran pada siswa jenjang Sekolah Menengah Atas dan Madrasah Aliyah. Data menunjukkan terdapat sekitar 1,2 miliar pelajar di seluruh dunia terpaksa harus belajar dari rumah akibat ditutupnya aktivitas tatap muka di sekolah dan universitas (Habiba et al. 2020). Sedangkan UNICEF melaporkan lebih dari 60 juta pelajar dan mahasiswa di Indonesia sementara tidak bersekolah karena pandemic COVID-19 (Sikirit 2020). Kondisi ini menimbulkan berbagai permasalahan terkait faktor-faktor yang dapat mempengaruhi tercapainya tujuan pembelajaran itu sendiri mulai dari kemampuan sekolah memfasilitasi pembelajaran online, kemampuan guru, media yang digunakan serta tingkat kesadaran dan ketahanan siswa dalam pembelajaran online (Yusuf 2017).

Beberapa penelitian mengenai pengaruh kondisi pandemic Covid-19 terhadap pembelajaran di sekolah, menjelaskan tingginya presentase tingkat ketegangan, kecemasan, dan kekhawatiran. Sebuah penelitian mengungkap 59\% siswa merasakan kecemasan dan 50\% siswa mengalami kesulitan berpikir (Abid Azhar and Iqbal 2018). Penelitian lain juga memberikan indikator kondisi kesehatan mental pada remaja yang menunjukkan gejala abnormal yang cukup tinggi pada hiperaktif dan masalah dengan teman sebaya terutama yang berkaitan dengan interaksi dan sosialisasi (Mathew 2014). Mengacu pada fakta tersebut, selain banyak faktor yang mempengaruhi, kondisi psikologis baik secara langsung maupun tidak langsung dapat mempengaruhi tingkat kebosanan dalam belajar yang secara langsung akan berdampak pada hasil belajar (Redhana 2019).

Di era pandemic Covid-19 ini, pembelajaran online bukan sekedar sebuah pembelajaran alternatif tetapi juga telah menjadi pembelajaran primer terutama dalam pembelajaran PAI pada jenajng madrasah aliyah. Untuk itu kegiatan pembelajaran merupakan dimensi yang harus diukur dan dikendalikan secara tersistem dan komprehensif. Kegiatan belajar siswa menjadi barometer pelayanan yang diberikan oleh sekolah/lembaga pendidikan (Tumar et al. 2015). Tingginya aktivitas pembelajaran menggambarkan komitmen para pelaksana dan pelaku dalam pembelajaran. Penerapan strategi, metode, dan model yang merupakan bagian dari perencanaan pembelajaran menjadi sarana untuk merangsang aktivitas belajar siswa (Satar and Akcan 2018).

Sejalan dengan uraian tersebut, konsep pembelajaran saat ini tidak lagi berpusat pada guru tetapi menjadi berpusat pada siswa di mana guru hanya sebagai fasilitator dan mentor (Panggabean and Himawan 2016). Keadaan ini memberikan kesempatan kepada siswa untuk mengembangkan kemampuannya seperti mengemukakan pendapat, berpikir kritis, menyampaikan gagasan dan sebagainya (Craig and Orland-Barak 2015). Pembelajaran aktif sangat dibutuhkan oleh siswa untuk mendapatkan hasil yang maksimal, apalagi di era proses pembelajaran online ini. Tingkat kemandirian siswa dalam belajar merupakan keniscayaan yang harus dapat dibimbing dan diwujudkan oleh sekolah melalui peran guru (Karomah 2017).

Selama diberlakukannya school from home (SFH), Madrasah Aliyah Nihayatul Amal Rawamerta kabupaten Karawang memberlakukan pembelajaran daring kepada seluruh siswanya. Pembelajaran dilaksanakan dengan memanfaatkan berbagai aplikasi yang mendukung dan dapat menghubungkan guru dengan siswa selama proses pembelajaran seperti googleclassroom, zoom meeting, google meeting dan fasilitas media sosial lainnya seperti WhatsApp yang digunakan sebagai ruang komunikasi dan interaksi untuk mendukung kelancaran proses pembelajaran online. Terkait dengan jadwal pembelajaran, MA Nihayatul Amal memberikan wewenang sepenuhnya kepada guru untuk mengelola pembelajaran sesuai tujuan dan 
2596 Tingkat Aktivitas Belajar Siswa Pada Pembelajaran Online Pendidikan Agama Islam di Masa Pandemi Covid-19 - Ayulia Septiani, Muhamad Taufik Bintang Kejora

DOI: https://doi.org/10.31004/edukatif.v3i5.914

kebutuhan peserta didik masing-masing. Kebijakan lain yang dilakukan oleh MA Nihayatul Amal mendukung pelaksanaan pembelajaran online adalah dengan mengirimkan dan menyiapkan buku ajar untuk diberikan kepada siswa, menyediakan akses internet di sekolah/madrasah bagi siswa yang tidak memiliki fasilitas, dan melakukan kunjungan kepada siswa yang kedapatan memiliki masalah pembelajaran yang sangat serius.

Beberapa penelitian mengenai aktivitas belajar online siswa yang telah dilakukan selama pandemi Covid-19 menunjukkan tingkat aktivitas pembelajaran berada pada kategori cukup baik (Sefriani et al. 2021) Selain itu, hasil penelitian tentang peningkatan aktivitas dan hasil belajar online dengan responden adalah siswa sekolah menggambarkan tingkat aktivitas sekitar 75,83\% (Ali and Maksum 2020). Terkait dengan pembelajaran tersebut juga terjadi peningkatan hasil belajar yang persentase ketuntasannya sekitar 90,27 (Okmawati 2020).

Penelitian lain yang dilakukan di masa pandemi Covid-19 lebih dominan fokus pada dampaknya terhadap proses pendidikan online dan hanya fokus pada satu mata pelajaran. Mereka belum mengukur perspektif siswa secara keseluruhan. Meninjau pada uraian di atas, maka penelitian yang berfokus pada survei tingkat aktivitas pembelajaran online pada rumpun pelajaran PAI di MA Nihayatul Amal Rawamerta sangat tepat dilakukan. Sebagaimana diketahui Bersama pada jenjang madrasah Aliyah terdapat 4 rumpun pelajaran PAI yaitu Aqidah Akhlak, Al-Qur'an Al-Hadits, Sejarah Kebudayaan Islam, dan Fiqh. Selain kelanjutan kerjasama, karakteristik responden, model pendidikan, perlakuan yang dilakukan berbeda dengan beberapa penelitian yang pernah dilakukan.

Fokus penelitian ini yang juga menjadi permasalahan penelitian adalah bagaimana tingkat keaktifan belajar siswa selama masa pandemi Covid-19. Tujuan utama dari penelitian ini adalah untuk mengetahui tingkat aktivitas belajar siswa dan untuk mengetahui strategi pembelajaran online di masa pandemi Covid-19 pada siswa MA Nihayatul Amal Rawamerta kabupaten Karawang. Penelitian ini tidak membatasi proses pembelajaran pada satu mata pelajaran saja tetapi difokuskan pada survei aktivitas belajar siswa pada 4 rumpun pelajaran PAI (Fiqh, Akidah Akhlak, Sejarah Kebudayaan Islam, dan Al-Qur'an Al-Hadits) di MA Nihayatul Amal Rawamerta kabupaten Karawang.

\section{METODE PENELITIAN}

Penelitian ini merupakan penelitian kuantitatif dengan metode survey (Creswell 2014). Tempat penelitian berada di Madrasah Aliyah Nihayatul Amal Rawamerta kabupaten Karawang. Instrumen penelitian menggunakan angket online dengan aplikasi google form tentang kegiatan dan aktivitas pembelajaran. Model pengumpulan data dengan model cross sectional (Sugiyono 2016). Responden atau subjek penelitian adalah siswa MA Nihayatul Amal sebanyak 105 siswa. Selain itu, analisis data menggunakan metode deskriptif kuantitatif Kusioner berskala likert ( 1- 5 ) digunakan untuk pengumpulan data aktivitas belajar (Nurabadi et al. 2021).

\section{Tabel 1}

\section{Skala Likert}

\begin{tabular}{lllll}
\hline Sangat Baik & Baik & Cukup & Rendah & Sangat Rendah \\
\hline 5 & 4 & 3 & 2 & 1 \\
\hline
\end{tabular}

Setelah data kuantitatif dikumpulkan, selanjutnya adalah menganalisa dan menentukan skor rata-rata setiap item. Data dalam bentuk skor atau angka diidentifikasi menggunakan interval Bringula dengan skala 5 poin penskoran (Salam 2020).

Tabel 2

Interprestasi Verbal

\begin{tabular}{cccc}
\hline No & Rentang Nilai/Skor & $\%$ & Kriteria \\
\hline 1. & $1,00-1,80$ & $20 \%-36 \%$ & Sangat Rendah \\
\hline 2. & $1,81-2,60$ & $37 \%-52 \%$ & Rendah \\
\hline
\end{tabular}


2597 Tingkat Aktivitas Belajar Siswa Pada Pembelajaran Online Pendidikan Agama Islam di Masa Pandemi Covid-19 - Ayulia Septiani, Muhamad Taufik Bintang Kejora

DOI: https://doi.org/10.31004/edukatif.v3i5.914

\begin{tabular}{cccc}
\hline No & Rentang Nilai/Skor & $\%$ & Kriteria \\
\hline 3. & $2,61-3,40$ & $53 \%-68 \%$ & Cukup \\
\hline 4. & $3,41-4,20$ & $69 \%-84 \%$ & Baik \\
\hline 5. & $4,21-5,00$ & $83 \%-100 \%$ & Sangat Baik \\
\hline
\end{tabular}

\section{HASIL DAN PEMBAHASAN PENELITIAN}

Deskripsi data yang disajikan dari hasil penelitian ini adalah untuk memberikan gambaran secara umum mengenai penyebaran data yang diperoleh di lapangan. Survei online terkait kegiatan belajar siswa secara online pada pelajaran rumpun PAI di MA Nihayatul Amal Rawamerta menjadi salah satu alternatif proses penelitian di tengah wabah pandemi Covid-19. Survei ini melibatkan 105 siswa sebagai responden yang terdiri dari 38 siswa laki-laki $(36,19 \%)$ dan 67 siswa perempuan $(63,81 \%)$. Sebaran responden secara rinci disajikan dalam tabel berikut:

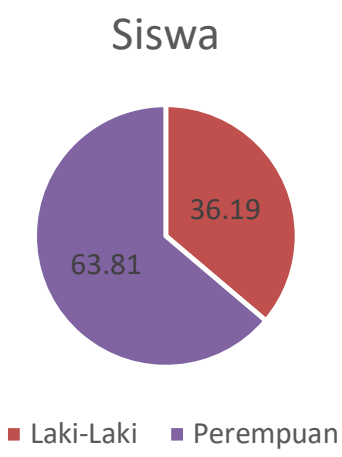

Gambar 1. Jumlah Responden Berdasarkan Gender

Tabel 3

Responden Penelitian

\begin{tabular}{lccccc}
\hline \multirow{2}{*}{ No } & \multirow{2}{*}{ kelas } & \multicolumn{2}{c}{ Jumlah Siswa } & \multirow{2}{*}{ Total } & $\%$ \\
& & Laki-Laki & Perempuan & & \multicolumn{1}{c}{ \% } \\
\hline 1 & X & 12 & 23 & 35 & 33,33 \\
2 & XI & 13 & 27 & 40 & 38,10 \\
3 & XII & 13 & 17 & 30 & 28,57 \\
\multicolumn{2}{c}{ Jumlah } & 38 & 67 & 105 & 100,00 \\
\hline
\end{tabular}

Pada bagian pembahasan ini kami deskripsikan hasil penelitian kegiatan pembelajaran online rupum pelajaran PAI siswa MA Nihayatul Amal selama pandemi Covid-19 yang dapat diuraikan sebagai berikut:

\section{Kehadiran/partisipasi siswa dalam pembelajaran online.}

Berdasarkan hasil angket siswa terkait tingkat kehadiran siswa dalam pelaksanaan pembelajaran online, dideskripsikan melalui tabel berikut:

Tabel 4

Kehadiran/partisipasi siswa dalam pembelajaran online

\begin{tabular}{cccccc}
\hline \multicolumn{1}{c}{ Indikator } & Selalu & Sering & $\begin{array}{c}\text { Kadang- } \\
\text { kadang }\end{array}$ & jarang & $\begin{array}{c}\text { Tidak } \\
\text { Pernah }\end{array}$ \\
\hline $\begin{array}{l}\text { Kehadiran/partisipasi siswa dalam } \\
\text { pembelajaran online }\end{array}$ & 35 & 38 & 16 & 16 & 0 \\
\multicolumn{1}{c}{ Prosentase (\%) } & 33,33 & 36,19 & 15,24 & 15,24 & 0,00 \\
\hline
\end{tabular}


2598 Tingkat Aktivitas Belajar Siswa Pada Pembelajaran Online Pendidikan Agama Islam di Masa Pandemi Covid-19 - Ayulia Septiani, Muhamad Taufik Bintang Kejora

DOI: https://doi.org/10.31004/edukatif.v3i5.914

Berdasarkan survey, siswa yang menjawab "selalu" dan "sering mengikuti" dikategorikan sebagai siswa aktif. Persentasenya 69,52\% atau ada 73 siswa dari 105 siswa. Sedangkan yang menjawab "kadang-kadang" dan "jarang" dikategorikan pasif. Persentasenya 30,48\% atau ada 32 siswa. Rata-rata kumulatif angket adalah 3,88 atau $77,52 \%$, data ini menjelaskan bahwa tingkat kehadiran atau partisipasi siswa dalam pembelajaran online berada pada kategori aktif atau baik.

Data tingkat kehadiran atau partisipasi tersebut diperkuat dengan data yang diperoleh dari angket siswa dalam mengikuti kegiatan pembelajaran online sampai pembelajaran selesai. Berdasarkan rekapitulasi data, terdapat $39(37,14 \%)$ siswa yang selalu mengikuti pembelajaran online sampai selesai, 32 siswa $(30,48 \%)$ sering mengikuti, 13 siswa (12,38\%) kadang-kadang mengikuti dan 21 siswa (20\%) jarang mengikuti. Ratarata kumulatif angket adalah 3,85 atau 76,95\%, data ini menjelaskan bahwa tingkat kehadiran siswa sampai pembelajaran online tuntas berada pada kategori aktif atau baik.

Tabel 5

Kehadiran/partisipasi siswa dalam pembelajaran online sampai pembelajaran tuntas

\begin{tabular}{lccccc}
\hline Indikator & Sll & Sering & Kadang2 & jarang & Tidak \\
\hline $\begin{array}{l}\text { Kehadiran/partisipasi siswa dalam } \\
\begin{array}{l}\text { pembelajaran online sampai } \\
\text { pembelajaran tuntas }\end{array}\end{array} \quad 39$ & 32 & 13 & 21 & 0 \\
$\quad$ Prosentase (\%) & 37,14 & 30,48 & 12,38 & 20,00 & 0,00 \\
\hline
\end{tabular}

Mengukur tingkat kedisiplinan siswa dalam mengikuti pembelajaran online hingga proses pembelajaran selesai menjadi penting karena dapat melihat sinergisitas antara aspek kehadiran dan partisipasi siswa untuk mengikuti pembelajaran hingga selesai. Aspek kehadiran yang termasuk kategori aktif mencapai $69,52 \%$ sedangkan yang mengikuti pembelajaran sampai selesai sebanyak 67,62\%. Ini menunjukkan antara siswa yang hadir dalam pembelajaran dengan siswa yang mengikuti pembelajaran sampai tuntas tidak terdapat selisih yang signifikan, hanya sebesar 1,9\% atau (satu atau dua siswa saja). Data tersebut dapat digunakan sebagai penegasan bahwa kehadiran dan partisipasi siswa untuk mengikuti pembelajaran sampai selesai memiliki harmoni yang baik.

\section{Mengerjakan atau menyelesaikan dan mengumpulkan tugas/pekerjaan rumah}

Berdasarkan hasil angket siswa terkait mengerjakan atau menyelesaikan dan mengumpulkan tugas/pekerjaan rumah, dideskripsikan melalui tabel berikut:

Tabel 6

Mengumpulkan Tugas

\begin{tabular}{cccccc}
\hline Indikator & Sll & Sering & Kadang2 & Jarang & Tidak \\
\hline $\begin{array}{c}\text { Mengerjakan atau menyelesaikan dan } \\
\text { mengumpulkan tugas/pekerjaan rumah }\end{array}$ & 72 & 20 & 13 & 0 & 0 \\
\begin{tabular}{c} 
Prosentase (\%) \\
\hline
\end{tabular} & 68,57 & 19,05 & 12,38 & 0,00 & 0,00 \\
\hline
\end{tabular}

Berdasarkan survey, siswa yang menjawab "selalu" dan "sering mengikuti" dikategorikan sebagai siswa aktif dalam mengerjakan dan mengumpulkan tugas. Persentasenya 87,62\% atau ada 92 siswa dari 105 siswa. Sedangkan yang menjawab "kadang-kadang" dan "jarang" dikategorikan pasif. Persentasenya 12,38\% atau ada 13 siswa. Rata-rata kumulatif angket adalah 4,56 atau 91,24\%, data ini menjelaskan bahwa tingkat keaktifan siswa dalam mengumpulkan tugas berada pada kategori sangat aktif atau sangat baik.

Uraian data tersebut secara gamblang menggambarkan bahwa keaktifan sebagian besar siswa dalam mengumpulkan tugas dalam pembelajaran online sudah sangat baik. Hal tersebut tentunya tidak lepas dari peran guru dalam kegiatan belajar mengajar. Peran guru dalam mengingatkan tugas/pekerjaan rumah siswa yang harus dilakukan dan dikumpulkan. 
2599 Tingkat Aktivitas Belajar Siswa Pada Pembelajaran Online Pendidikan Agama Islam di Masa Pandemi Covid-19 - Ayulia Septiani, Muhamad Taufik Bintang Kejora

DOI: https://doi.org/10.31004/edukatif.v3i5.914

Guna memastikan sejauhmana interaksi guru dengan siswa saling mengingatkan dalam mengumpulkan tugas, dilakukan survey terhadap 105 siswa. Hasilnya adalah 53 siswa (50,48\%) merasa selalu diingatkan, 29 siswa $(27,62 \%)$ sering diingatkan, 16 siswa $(15,24 \%)$ kadang-kadang diingatkan, dan 7 siswa $(6,67 \%)$ jarang diingatkan. Rata-rata kumulatif angket adalah 4,22 atau 84,38\%, data ini menjelaskan bahwa tingkat keaktifan guru dalam mengingatkan siswa untuk mengumpulkan tugas berada pada kategori sangat aktif atau sangat baik.

Tabel 7

Diingatkan Tentang Pengumpulan Tugas

\begin{tabular}{lccccc}
\hline \multicolumn{1}{c}{ Indikator } & Sll & Sering & Kadang2 & Jarang & Tidak \\
\hline $\begin{array}{l}\text { Diingatkan untuk menyelesaikan dan } \\
\begin{array}{l}\text { mengumpulkan tugas/pekerjaan } \\
\text { rumah }\end{array}\end{array}$ & 53 & 29 & 16 & 7 & 0 \\
$\quad$ Prosentase (\%) & 50,48 & 27,62 & 15,24 & 6,67 & 0,00 \\
\hline
\end{tabular}

Uraian diatas menunjukkan bahwa peran guru mengingatkan siswa untuk mengumpulkan tugas memberi dampak positif terhadap keaktifan siswa mengumpulkan tugas. Semakin aktif guru mengingatkan maka siswa pun semakin aktif mengumpulkan tugas pembelajaran online.

\section{Muroja'ah Juz 30}

Murojaah atau menghafal Al-Qur'an juz 30 dilakukan dengan beberapa cara yaitu dilakukan di depan guru dengan menggunakan video call secara langsung atau memanfaatkan rekaman video yang dikirimkan melalui google classroom atau WhatsApp. Kegiatan ini merupakan kegiatan unggulan untuk meningkatkan kuantitas dan kualitas hafalan Al-Qur'an Juz 30 bagi siswa.

Tabel 8

Muroja'ah

\begin{tabular}{cccccc}
\hline Indikator & Sll & Sering & Kadang2 & Jarang & Tidak \\
\hline Muroja'ah juz 30 & 42 & 47 & 9 & 5 & 2 \\
Prosntase (\%) & 40,00 & 44,76 & 8,57 & 4,76 & 1,90 \\
\hline
\end{tabular}

Berdasarkan survey, siswa yang menjawab "selalu" dan "sering mengikuti" dikategorikan sebagai siswa aktif dalam melakukan muroja'ah. Persentasenya 84,76\% atau ada 89 siswa dari 105 siswa. Sedangkan yang menjawab "kadang-kadang" dan "jarang" dikategorikan pasif. Persentasenya 13,33\% atau ada 14 siswa. Ratarata kumulatif angket adalah 4,16 atau 83,24\%, data ini menjelaskan bahwa tingkat keaktifan siswa dalam melaksanakan muroja' ah juz 30 secara online pada kategori aktif atau baik.

\section{Menghafal mufrodat / kosa kata}

Menghafal mufrodat/kosakata sebagai salah satu faktor penunjang keunggulan siswa dalam mencapai kefasihan dalam menggunakan bahasa Arab merupakan kegiatan yang harus dilakukan selama pembelajaran online. Untuk kegiatan hafalan siswa, pemantauan dilakukan dengan cara video call atau pengiriman rekaman kepada pembimbing.

Tabel 9

Menghafal Mufrodat

\begin{tabular}{|c|c|c|c|c|c|}
\hline Indikator & Sll & Sering & Kadang2 & Jarang & Tidak \\
\hline Mufradat/Hafalan Kosakata & 33 & 37 & 19 & 11 & 5 \\
\hline Prosentase $(\%)$ & 31,43 & 35,24 & 18,10 & 10,48 & 4,76 \\
\hline
\end{tabular}

Tingkat pencapaian kegiatan ini dalam kategori selalu menyetorkan hafalan tercapai $31,43 \%$ atau 33 siswa, sering 35\% atau 37 siswa, kadang-kadang 18,10\% atau 19 siswa, jarang 10,48\% atau 11 siswa, dan tidak menyetorkan hafalan $4,76 \%$ atau 5 siswa. Rata-rata kumulatif angket adalah 3,78 atau 75,62\%, data ini 
2600 Tingkat Aktivitas Belajar Siswa Pada Pembelajaran Online Pendidikan Agama Islam di Masa Pandemi Covid-19 - Ayulia Septiani, Muhamad Taufik Bintang Kejora

DOI: https://doi.org/10.31004/edukatif.v3i5.914

menjelaskan bahwa tingkat keaktifan siswa dalam melaksanakan setoran mufrodat secara online pada kategori aktif atau baik.

\section{Aktivitas Bertanya}

Kegiatan bertanya merupakan bagian dari kegiatan lisan dan menggambarkan tingkat berpikir kritis siswa dalam pembelajaran secara online. Deskripsi data yang terkait dengan aspek ini dapat divisualisasikan sebagai dasar untuk menggambarkan aktivitas siswa dalam pembelajaran online dalam data kuantitatif.

Tabel 10

Aktivitas Bertanya

\begin{tabular}{|c|c|c|c|c|c|c|}
\hline Indikator & & Sll & Sering & Kadang2 & jarang & Tidak \\
\hline Aktivitas Bertanya & & 17 & 23 & 38 & 18 & 9 \\
\hline & Prosentase $(\%)$ & 16,19 & 21,90 & 36,19 & 17,14 & 8,57 \\
\hline
\end{tabular}

Rata-rata kumulatif angket mengenai aktivitas bertanya siswa adalah 3,20 atau 64\%, data ini menjelaskan bahwa tingkat keaktifan siswa bertanya dalam pembelajaran secara online pada kategori cukup aktif atau cukup baik. Kegiatan tanya jawab ini lebih berfokus pada permasalahan yang dihadapi saat pembelajaran online dilaksanakan. Hal ini berkaitan dengan kesulitan atau kurangnya pemahaman terhadap materi pembelajaran yang diterima siswa.

\section{Diskusi}

Diskusi merupakan bagian dari kegiatan pembelajaran yang menuntut siswa belajar aktif, komunikatif dan kolaboratif antara satu sama lain. Tujuan diskusi selain pendalaman materi juga untuk mengajarkan siswa menemukan solusi atas sebuah kasus atau persoalan yang dihadapi baik sifatnya tekstual maupun kontekstual.

\section{Tabel 11}

Diskusi

\begin{tabular}{|c|c|c|c|c|c|c|}
\hline Indikator & & Sll & Sering & Kadang2 & jarang & Tidak \\
\hline Diskusi & & 22 & 23 & 29 & 20 & 2 \\
\hline & Prosentase $(\%)$ & 20,95 & 21,90 & 27,62 & 19,05 & 1,90 \\
\hline
\end{tabular}

Berdasarkan data kegiatan dikusi siswa selama pembelajaran online, rata-rata kumulatif angket mengenai aktivitas diskusi siswa adalah 3,15 atau 63,05\%. Data ini menjelaskan bahwa tingkat keaktifan siswa berdikusi dalam pembeeljaran secara online pada kategori cukup aktif atau cukup baik. Terdapat 45 siswa yang aktif dan sisanya 60 siswa merupakan siswa yang pasif dalam aktivitas diskusi.

\section{Membaca atau mereview materi pembelajaran}

Membaca atau mempelajari kembali materi pembelajaran merupakan kegiatan belajar yang berjenis kegiatan visual. Kegiatan ini merupakan domain yang dominan untuk membantu siswa mencapai hasil belajar yang baik. Data aktivitas siswa dalam membaca atau mempelajari kembali materi yang diperoleh dari pembelajaran online adalah sebagai berikut:

Tabel 12

Mereview Materi Pembelajaran

\begin{tabular}{|c|c|c|c|c|c|c|}
\hline Indikator & & Sll & Sering & Kadang2 & Jarang & Tidak \\
\hline \multicolumn{7}{|c|}{ Membaca atau Mereview Materi } \\
\hline Pembelajaran & & 15 & 13 & 53 & 4 & 20 \\
\hline & Prosentase $(\%)$ & 14,29 & 12,38 & 50,48 & 3,81 & 19,05 \\
\hline
\end{tabular}

Berdasarkan data kegiatan mereview materi pembelejeran selama pembelajaran online, rata-rata kumulatif angket mengenai aktivitas mereview siswa adalah 2,99 atau 59,81\%. Data ini menjelaskan bahwa tingkat keaktifan siswa melakukan review materi pembelajaran pada kategori cukup aktif atau cukup baik. 
2601 Tingkat Aktivitas Belajar Siswa Pada Pembelajaran Online Pendidikan Agama Islam di Masa Pandemi Covid-19 - Ayulia Septiani, Muhamad Taufik Bintang Kejora

DOI: https://doi.org/10.31004/edukatif.v3i5.914

Terdapat 28 siswa yang aktif dan sisanya 87 siswa merupakan siswa yang pasif dalam aktivitas mereview materi pembelajaran.

Berdasarkan data tersebut, terdapat beberapa aktivitas siswa dalam pembelajaran online pada masa pandemi Covid-19 diantaranya adalah aktivitas absensi atau partisipasi siswa dalam pembelajaran online yang didukung dengan data siswa yang mengikuti proses pembelajaran sampai selesai., menyelesaikan dan mengumpulkan tugas/pekerjaan rumah, murojaah materi Al-Qur'an, menghafal mufrodat/kosa kata, bertanya, berdiskusi dan membaca atau mempelajari kembali materi pembelajaran. Masing-masing aspek tersebut dapat divisualisasikan dalam diagram berikut:

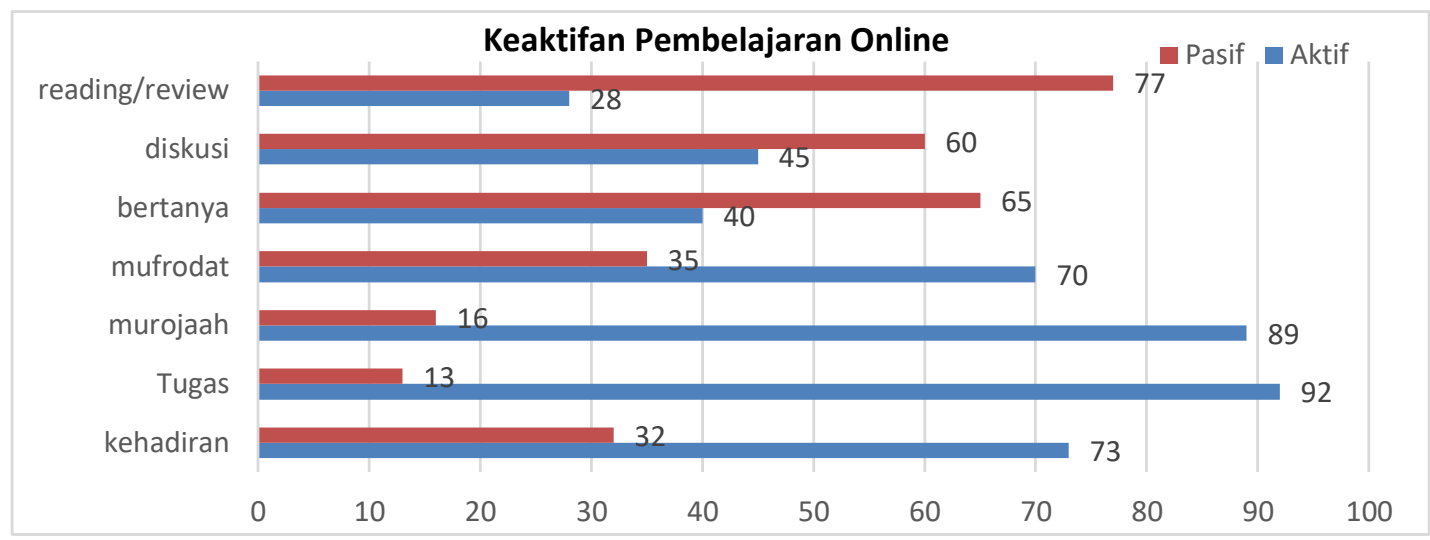

Gambar 2. Jumlah Siswa Aktif dan Pasif dalam Pembelajaran Online

Mengacu pada visualisasi data pada diagram, kategori aktif tingkat aktivitas dari yang tertinggi hingga terendah dapat diurutkan sebagai berikut: mengumpulkan tugas (92 siswa), murojaah kegiatan Al-Qur'an (89 siswa), kehadiran (73 siswa), mufrodat (70 siswa), diskusi (45 siswa), bertanya (40 siswa), dan review (28 siswa). Dari deskripsi data ini, dapat dibangun visualisasi untuk melihat kontribusi dari setiap kegiatan, seperti gambar dibawah ini:

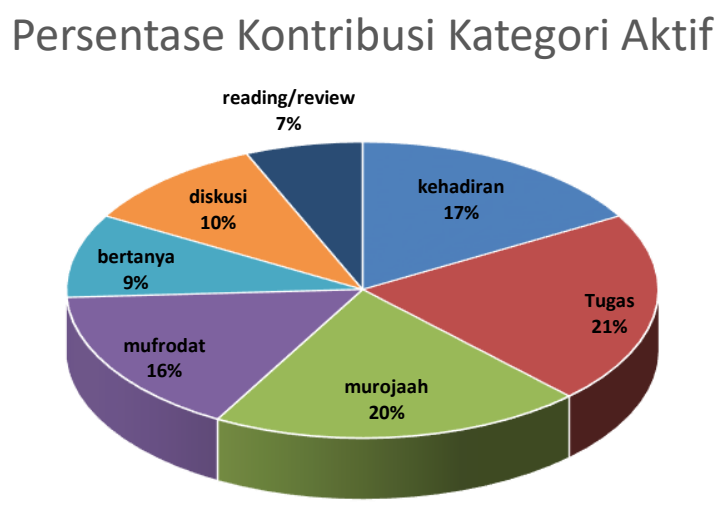

\section{Gambar 3. Persentase Kontribusi Kategori Aktif}

Data pada gambar di atas secara eksplisit menunjukkan bahwa persentase tertinggi disumbangkan oleh murojaah dan persentase terendah adalah pada aktivitas mereview materi pembelajaran. Artinya bahwa keaktifan siswa dalam mereview atau membaca materi pembelajeran perlu mendapat perhatian serius.

Merujuk pada teori aktivitas belajar, dari hasil penelitian ini dapat dikemukakan bahwa aspek kehadiran siswa dapat dimasukkan dalam aktivitas emosional, mengerjakan dan mengumpulkan tugas/pekerjaan rumah dapat dimasukkan dalam dua ranah, yaitu aktivitas menulis dan menggambar. Murojaah dan kegiatan menghafal termasuk ke dalam kegiatan mental yang berkaitan dengan proses ingatan, kegiatan diskusi dan bertanya merupakan bagian dari kegiatan lisan dan membaca merupakan bagian dari 
2602 Tingkat Aktivitas Belajar Siswa Pada Pembelajaran Online Pendidikan Agama Islam di Masa Pandemi Covid-19 - Ayulia Septiani, Muhamad Taufik Bintang Kejora

DOI: https://doi.org/10.31004/edukatif.v3i5.914

kegiatan visual(Rahmi 2020). Tingkat aktivitas belajar tidak dapat dipisahkan dari perannya sebagai indikator pembelajaran yang efektif dan efisien, termasuk dalam proses pembelajaran online (Hapsari and Pamungkas 2019).

Pelaksanaan pembelajaran online harus dikelola dengan baik dan sistematis, hal ini karena pembelajaran jarak jauh yang merupakan konsep dasarnya memerlukan perencanaan yang komprehensif mulai dari metode hingga bahan ajar. Terakhir, pembelajaran yang efektif dan efisien dapat menumbuhkan pembelajaran mandiri sebagai fasilitator untuk menumbuhkan aktivitas belajar siswa yang baik (Noorjannah 2014).

Selain pemerataan akses pendidikan, tujuan dasar pembelajaran online atau distance learning adalah untuk menciptakan kemandirian siswa dalam belajar (Siahaan and Rivalina 2012). Pembelajaran online juga harus memperhatikan media, alat, aplikasi dan perangkat lain yang digunakan dalam pelaksanaannya. Kegiatan pembelajaran online yang menggunakan media google classroom, zoom, whatsapp, dapat dijadikan sebagai salah satu faktor yang mempengaruhi aktivitas belajar siswa yang tergolong baik atau tinggi (So 2016). Hal ini sejalan dengan beberapa hasil penelitian terkait penggunaan fasilitas dan media tersebut dalam pelaksanaan pembelajaran online khususnya WhatsApp. Aplikasi WhatsApp digunakan untuk fasilitas pembelejeran yaitu murojaah yang persentase aktivitas belajarnya tinggi atau baik (Anugrahana 2020).

Manajemen MA Nihayatul Amal dalam mendukung proses pelaksanaan pembelajaran online disikapi dengan keharusan bagi guru untuk membuat resume yang dapat dijadikan bahan ajar. Fungsi bahan ajar adalah sebagai sarana untuk memperlancar proses pembelajaran agar efektif (Rahmi 2020). Berdasarkan data penelitian, tingkat aktivitas belajar siswa pada pelaksanaan pembelajaran online yang dikategorikan baik dapat dikaitkan dengan peran guru. Dinamika hubungan dan komunikasi guru atau sekolah tercermin dalam pelaksanaan kegiatan nonformal dan ekstrakurikuler yang dilaksanakan. Meskipun pembelajaran mandiri telah menjadi orientasi dalam pembelajaran online dan terjadi pergeseran paradigma dalam konteks pembelajaran yang berpusat pada siswa, peran guru tetap tidak dapat dikesampingkan (Panggabean and Himawan 2016).

Peran guru dalam pembelajaran online menjadi penting, karena secara psikologis peran guru tetap diperlukan dalam mendorong siswa terlibat aktif dalam pembelajaran. Kehadiran guru mampu meningkatkan mampu mengatasi kejenuhan siswa baik secara fisik maupun psikologis dalam mengikuti pembelajaran (Kagema and Irungu 2018). Perlakuan yang dilakukan pihak sekolah dengan mengurangi durasi jam pelajaran dan menjadikan kewajiban guru untuk mengembangkan bahan ajar berupa resume atau handout menjadi pemecahan masalah untuk mengatasi permasalahan yang dihadapi siswa dalam mencapai tujuan pembelajaran (Srinivasacharlu 2019). Hal ini terlihat jelas pada aspek mengingatkan siswa untuk mengerjakan dan mengumpulkan tugas/pekerjaan rumah sehingga persentase pencapaian kategori aktif aspek ini mencapai $77,52 \%$.

Kebijakan sekolah dan peran guru berdampak baik terhadap aktivitas belajar siswa dalam pembelajaran online (Shahali, Halim, and Treagust 2015). Ini ditunjukkan oleh kehadiran siswa, muroja'ah, dan mufrodat, yang dalam kategori baik. Demikian pula dengan keaktifan dalam mengumpulkan tugas sudah berjalan sangat baik. Dan aktivitas bertanya dan berdiskusi sudah cukup baik namun perlu ditingkatkan lebih lanjut. Tingkat kegiatan yang baik ini sejalan dengan dimensi keunggulan yang menjadi fokus MA Nihayatul Amal Rawamerta yaitu, target siswa mampu menuntaskan hafalan 30 juz Al-Qur'an dan mempraktikkan komunikasi sehari-hari dengan menggunakan Arab. Kedua aspek tersebut adalahmendukung komponen untuk mewujudkan tujuan keunggulan sekolah.

Perlakuan yang juga diterapkan berdasarkan hasil wawancara dengan kepala MA Nihayatul Amal Rawamerta kab. Karawang dalam pelaksanaan kegiatan pembelajaran online adalah menginstruksikan kepada guru untuk melakukan evaluasi berkala terkait pelaksanaan pembelajaran online setiap bulannya. Proses evaluasi ini secara signifikan mampu mengontrol dan memposisikan pelaksanaan pembelajaran online agar selalu berada pada jalur yang sesuai dengan layanan pendidikan sehingga dampak nyata dapat dilihat pada 
2603 Tingkat Aktivitas Belajar Siswa Pada Pembelajaran Online Pendidikan Agama Islam di Masa Pandemi Covid-19 - Ayulia Septiani, Muhamad Taufik Bintang Kejora

DOI: https://doi.org/10.31004/edukatif.v3i5.914

tingkat aktif atau baik aktivitas belajar siswa. Singkatnya,MA Nihayatul Amal memelihara dan membina kegiatan belajar siswa dalam pembelajaran online dengan menyelenggarakan semua kegiatan yang biasanya dilakukan dalam kondisi offline.

Penelitian (Hafida 2020) menunjukkan bahwa selama masa pandemic terjadi penurunan motivasi dan keaktifan belajar siswa. Sementara itu hasil yang berbeda ditunjukkan Setiawan, Sofyan Rofi, and Tri Endang Jatmikowati (2021) dalam penelitiannya. Mereka telah mengkaji sebuah studi mengenai keaktifan belajar siswa dalam pembelajaran online di masa pandemic dengan focus penelitian pada studi kasus di Pesantren AlAmin Muhammadiyah Bojonegoro. Dan penelitian Al Halik and Aini (2020) menunjukkan bahwa secara umum keaktifan siswa dalam proses pembelajaran daring berkategori tinggi. Sementara penelitian yang penulis lakukan menunjukkan keaktifan belajar siswa dalam pembelajaran online Pendidikan Agama Islam termasuk kategori baik/aktif/tinggi. Hasil survey menggambarkan bahwa siswa aktif dalam kehadiran di kelas online (77,72\%), mengikuti pembelajaran sampai selesai $(69,52 \%)$, mengumpulkan tugas $(91,24 \%)$, muroja'ah $(84,, 76 \%)$, mufrodat $(75,62 \%)$, bertanya $(64 \%)$, berdiskusi $(63,05 \%)$ dan mereview materi pembelejaran $(59,81 \%)$. Secara umum siswa MA Nihayatul Amal memiliki keaktifan belajar yang baik atau tinggi. Namun demikian aspek yang perlu ditingkatkan dan perlu mendapat perhatian serius adalah pada aspek mereview atau membaca materi pembelajaran.

Keaktifan siswa dalam pembelajaran daring dapat menunjukkan hasil yang bervariasi. Artinya hasil penelitian tidak dapat digeneralisir untuk semua jenjang dan kondisi lingkungan belajar. Hal ini dipengaruhi beberapa faktor seperti kompetensi mengajar guru dalam pembelajaran online, kemampuan guru dalam memeantau aktivitas siswa pada proses pembelajaran, siswa membutuhkan penjelasan langsung secara verbal dari guru, ketersediaan layanan internet, biaya lebih yang diperlukan dalam pembelajaran, daring, kemandirian belajar siswa, dan penggunaan gadget yang berlebihan oleh siswa. Perlu adanya kerjasama pemantauan oleh guru dan orang tua, dimana waktu belajar dan waktu bermain harus diatur, sehingga nantinya siswa dapat terbiasa untuk mengontrol waktunya tidak hanya untuk bermain saja namun juga perlu menambah semangat belajar. Pada beberapa kasus justru menunjukkan siswa mahir dalam menggunakan gadget dan teknologi internet, namun mereka kesulitan mengontrol diri untuk menghhindari game dan media social daripada menggunakannya untuk aktivitas pembelajaran (Ucan 2016). Untuk itu penting pula bagi guru membuat suasana belajar yang menyenangkan, entah dengan mengganti model pembelajaran, metode pembelajaran dan lain-lain (Trisnamansyah 2014).

Hasil analisis data penelitian ini, dapat dijadikan need assessment (analisis kebutuhan) bagi guru Pendidikan Agama Islam dalam perencanaan, perancangan, pelaksanaan dan pengevaluasian pembelajaran PAI secara online di masa pendemic. Penelitian ini juga masih terdapat keterbatasan dan kelemahan. Diharapkan penelitian dapat dilakukan dengan cakupan subjek dan lokasi penelitian lebih luas lagi, sehingga hasil generalisasi tidak hanya sebatas subjek dalam penelitian ini saja, yang jumlahnya masih relatif terbatas. Dan perlu pula bagi peneliti selanjutnya melakukan pengembangan berkenaan dengan variabel lain yang diduga berkontribusi terhadap keaktifan siswa dalam belajar sehingga hasil penelitian lebih komprehensif.

\section{KESIMPULAN}

Tingkat aktivitas belajar siswa dalam pembelajaran rumpun PAI dengan pembelajaran daring dalam kategori baik atau aktif. Kendati demikian perlu ditingkatkan aspek keaktifan dikusi dan aktivitas review atua membaca materi pembelajaran. Tingkat aktivitas belajar siswa tidak dapat dilepaskan dari peran guru dan kebijakan sekolah. Sehebat apapun teknologi tidak dapat menggantikan peran guru sebagai motivator dan inspirator. Meskipun demikian, teknologi ditangan guru yang tepat, akan memberikan lompatan hebat dalam dunia pendidikan. Demikian kebijakan MA Nihayatul Amal dalam pembelajaran online antara lain pengurangan durasi jam pelajaran, mewajibkan guru membuat resume materi pelajaran, menggunakan media 
2604 Tingkat Aktivitas Belajar Siswa Pada Pembelajaran Online Pendidikan Agama Islam di Masa Pandemi Covid-19 - Ayulia Septiani, Muhamad Taufik Bintang Kejora

DOI: https://doi.org/10.31004/edukatif.v3i5.914

yang fleksibel seperti google classroom, zoom meeting dan whatsapp, sangat memfasilitasi guru dan siswa mencapai tujuan dan aktivitas pembelajaran secara optimal.

\section{DAFTAR PUSTAKA}

Abid Azhar, Kaukab, and Nayab Iqbal. 2018. "Effectiveness of Google Classroom: Teachers' Perceptions." Prizren Social Science Journal 2(2):52-66.

Ali, Muttaqin Kholis, and Hasan Maksum. 2020. "Utilization of E-Learning-Based ICT Learning Using the Google Classroom Application During the COVID-19 Pandemic." Journal of Education Research and Evaluation 4(4):373-79. doi: 10.23887/jere.v4i4.29181.

Anugrahana, Andri. 2020. "Hambatan, Solusi Dan Harapan: Pembelajaran Daring Selama Masa Pandemi Covid-19 Oleh Guru Sekolah Dasar." Scholaria: Jurnal Pendidikan Dan Kebudayaan 10(3):282-89. doi: 10.24246/j.js.2020.v10.i3.p282-289.

Craig, Cheryl J., and Lily Orland-Barak. 2015. "International Teacher Education: Promising Pedagogies Introduction." Advances in Research on Teaching 22B(January):1-5. doi: 10.1108/S1479368720150000025045.

Creswell, J. W. 2014. Research Design Qualitative, Quantitative, and Mixed Method Approaches. California: SAGE Publication. Inc.

Dewi, Wahyu Aji Fatma. 2020. "Dampak COVID-19 Terhadap Implementasi Pembelajaran Daring Di Sekolah Dasar." Edukatif: Jurnal Ilmu Pendidikan 2(1):55-61. doi: 10.31004/edukatif.v2i1.89.

Habiba, Bella, Sri Mulyani, Nia Ifa Nia, and Puspo Nugroho. 2020. "Konsep Layanan Responsif Bagi Siswa Yang Mengalami Kesulitan Belajar Secara Daring Dimasa Pandemi Covid-19." KONSELING EDUKASI “Journal of Guidance and Counseling” 4(2):305-22. doi: 10.21043/konseling.v4i2.7583.

Hafida, dkk. 2020. "Penurunan Motivasi Dan Keaktifan Belajar Siswa Selama Pembelajaran Daring Di Tengah Pendemi Covid-19." Indonesian Journal Of Education Scince 2(2):82.

Al Halik, and Zamratul Aini. 2020. "Analisis Keaktifan Siswa Dalam Proses Pembelajaran Daring Di Masa Pandemi COVID-19." ENLIGHTEN (Jurnal Bimbingan Dan Konseling Islam) 3(2):131-41. doi: 10.32505/enlighten.v3i2.1887.

Handarini, Oktavia Ika. 2020. "Pembelajaran Daring Sebagai Upaya Study From Home (SFH) Selama Pandemi Covid 19 Oktafia." Jurnal Pendidikan Administrasi Perkantoran (JPAP) 8(3):496-503. doi: 10.1093/fampra/cmy005.

Hapsari, Swita Amallia, and Heri Pamungkas. 2019. "Pemanfaatan Google Classroom Sebagai Media Pembelajaran Online Di Universitas Dian Nuswantoro." WACANA: Jurnal Ilmiah Ilmu Komunikasi 18(2). doi: 10.32509/wacana.v18i2.924.

Kagema, Josphat, and Cecilia Irungu. 2018. "An Analysis of Teacher Performance Appraisals and Their Influence on Teacher Performance in Secondary Schools in Kenya." International Journal of Education 11(1):93. doi: 10.17509/ije.v11i1.11148.

Karomah, Siti. 2017. "Improving Teacher Performance Competence in Teaching Students through Technology Information And Communications in Elementary School 30 Timbulun." Jurnal Ilmiah Pendidikan Scholastic 1(1):79-89.

Mathew, David. 2014. "E-Learning, Time and Unconscious Thinking." E-Learning and Digital Media 11(2):135-40. doi: 10.2304/elea.2014.11.2.135.

Noorjannah, Lilies. 2014. "Pengembangan Profesionalisme Guru Melalui Penulisan Karya Tulis Ilmiah Bagi Guru Profesional di SMA Negeri 1 Teacher Professionalism Development Through Writing Scientific Papers For Teachers In Professional SMA Negeri 1 Kauman District Tulungagung Guru A." Jurnal Humanity 10:97-114. 
2605 Tingkat Aktivitas Belajar Siswa Pada Pembelajaran Online Pendidikan Agama Islam di Masa Pandemi Covid-19 - Ayulia Septiani, Muhamad Taufik Bintang Kejora

DOI: https://doi.org/10.31004/edukatif.v3i5.914

Nurabadi, Ahmad, Jusuf Irianto, Ibrahim Bafadal, Juharyanto, Imam Gunawan, and Maulana Amirul Adha. 2021. "The Effect of Instructional, Transformational and Spiritual Leadership on Elementary School Teachers' Performance and Students' Achievements." Cakrawala Pendidikan 40(1):17-31. doi: 10.21831/cp.v40i1.35641.

Okmawati, Mike. 2020. "The Use of Google Classroom during Pandemic." Journal of English Language Teaching 9(2):438. doi: 10.24036/jelt.v9i2.109293.

Panggabean, Meicky Shoreamanis, and Karel Karsten Himawan. 2016. "The Development of Indonesian Teacher Competence Questionnaire." Journal of Educational, Health and Community Psychology 5(2):1. doi: 10.12928/jehcp.v5i2.5134.

Rahmi, Rina. 2020. "Al-Tarbiyah: Jurnal Pendidikan ( The Educational Journal ) Inovasi Pembelajaran di Masa Pandemi Covid-19." 30(2):111-23. doi: 10.24235/ath.v.

Redhana, I. Wayan. 2019. "Mengembangkan Keterampilan Abad Ke-21 Dalam Pembelajaran Kimia.” Jurnal Inovasi Pendidikan Kimia 13(1).

Salam, U. 2020. “The Students' Use of Google Classroom in Learning English.” JPI (Jurnal Pendidikan Indonesia) 9(4):628-38. doi: 10.23887/jpi-undiksha.v9i4.27163.

Satar, H. Müge, and Sumru Akcan. 2018. "Pre-Service EFL Teachers' Online Participation, Interaction, and Social Presence." Language Learning and Technology 22(1):157-84.

Sefriani, Rini, Rina Sepriana, Indra Wijaya, Popi Radyuli, and Menrisal. 2021. "Blended Learning with Edmodo: The Effectiveness of Statistical Learning during the Covid-19 Pandemic." International Journal of Evaluation and Research in Education 10(1):293-99. doi: 10.11591/IJERE.V10I1.20826.

Setiawan, Bahar, Sofyan Rofi, and Tri Endang Jatmikowati. 2021. "The Student Learning Activity Levels on the Online Learning During the Covid-19 Pandemic." Jurnal Pendidikan Islam Indonesia 5(2):186-97. doi: 10.35316/jpii.v5i2.289.

Shahali, E. H. M., L. Halim, and D. F. Treagust. 2015. "Primary School Teachers' Understanding of Science Process Skills in Relation to Their Teaching Qualifications and Teaching Experience." Research Science in Education 47(1).

Siahaan, Sudirman, and Rahmi Rivalina. 2012. "Perkembangan Pendidikan Terbuka Dan Jarak Jauh Di Indonesia." Jurnal Teknodik 16 No. 1:59-72.

Sikirit, David. 2020. "Learning from Home during the COVID-19 Pandemic With Her School Closed, 6-YearOld Moreyna Strives to Continue Learning at Home in Papua." UNICEF Indonesia. Retrieved (https://www.unicef.org/indonesia/coronavirus/stories/learning-home-during-covid-19-pandemic).

So, Simon. 2016. "Mobile Instant Messaging Support for Teaching and Learning in Higher Education." Internet and Higher Education 31:32-42. doi: 10.1016/j.iheduc.2016.06.001.

Srinivasacharlu, A. 2019. "Continuing Professional Development (CPD) of Teacher Educators in 21st Century." Shanlax International Journal of Education 7(4):29-33. doi: 10.34293/education.v7i4.624.

Sugiyono. 2016. Metode Penelitian Kombinasi (Mix Methode). Bandung: Alfabeta.

Susanna, Dewi. 2020. "When Will the COVID-19 Pandemic in Indonesia End?" Kesmas 15(4):160-62. doi: 10.21109/KESMAS.V15I4.4361.

Trisnamansyah, Sutaryat. 2014. Evalausi Pembelajaran. Bandung: Pustaka Setia.

Tumar, Annyza Binti, Soaib Asimiran, Zaidatol Akmaliah Lope Pihie, and Ismi Arif Ismail. 2015. "Sustaining Continuous Professional Development for Quality Teaching and Learning in Higher Education: The Role of Policy and Policy Implementers." Turkish Online Journal of Educational Technology 2015(August):527-34.

Ucan, Serkan. 2016. "The Role of Continuous Professional Development of Teachers in Educational Change: A Literature Review." Harran Education Journal 1(1):36-43. doi: 10.22596/2016.0101.36.43. 
2606 Tingkat Aktivitas Belajar Siswa Pada Pembelajaran Online Pendidikan Agama Islam di Masa Pandemi Covid-19-Ayulia Septiani, Muhamad Taufik Bintang Kejora

DOI: https://doi.org/10.31004/edukatif.v3i5.914

Yusuf, Bistari Basuni. 2017. “Konsep Dan Indikator Pembelajaran Efektif.” Jurnal Kajian Pembelajaran Dan Keilmuan 1(2):13-20. 